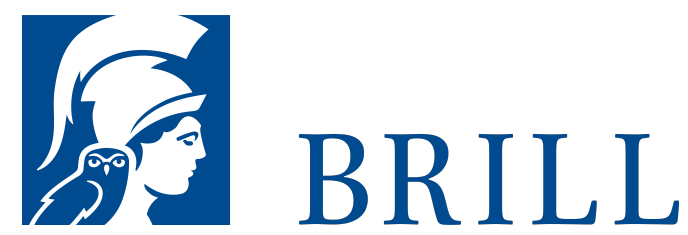

\title{
When Women Interfere
}

Studies in the Role of Women in Herodotus' Histories

Author: Minke W. Hazewindus

Hazewindus, M.W. When Women Interfere. Studies in the Role of Women in Herodotus' Histories. 2004

In his Histories, Herodotus presents several short stories that seem at odds with the main story and that are therefore sometimes dismissed as mere anecdotes. In this book, Dr. Hazewindus analyzes five of such short stories in order to establish their function in the work as a whole. In these short stories women play important roles. The author shows that these roles exhibit a pattern: women unexpectedly change from passive, silent characters into active, leading people who at times take a bloody revenge when they feel wronged. Women here turn the wheel of history. When the main story is resumed, they disappear again into the background. Nevertheless, the women stories give a unique colour to the Histories, and a proper understanding of them enriches our interpretation of Herodotus' work.

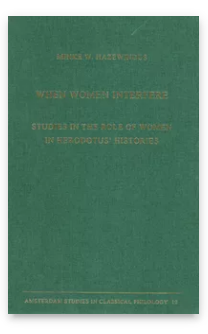

Pages: 264 pp.

Language:

English

Subjects: Greek

\& Latin

Literature,

Classical Studies

Publisher: Brill

Series:

Amsterdam

Studies in

Classical

Philology,

Volume: 12

E-Book (PDF)

Released online: 16 Sep 2019

ISBN: 978-90-

04-40907-1

List price

USD $\$ 128.00$

Hardback

Publication date:

o1 Jan 2004

ISBN: 978-90-

50-63449-6

List price

USD $\$ 128.00$ 
For more information see brill.com

Order information: Order online at brill.com +44330 333 0049 | customerservices@brill.com Submission information: brill.com/authors

Titles published by Brill | Fink, Brill | mentis or Brill | Schöningh: +49(o)715413279216| brill@brocom.de 